\title{
The delay of the Day of the Lord in Malachi: A missional reading
}

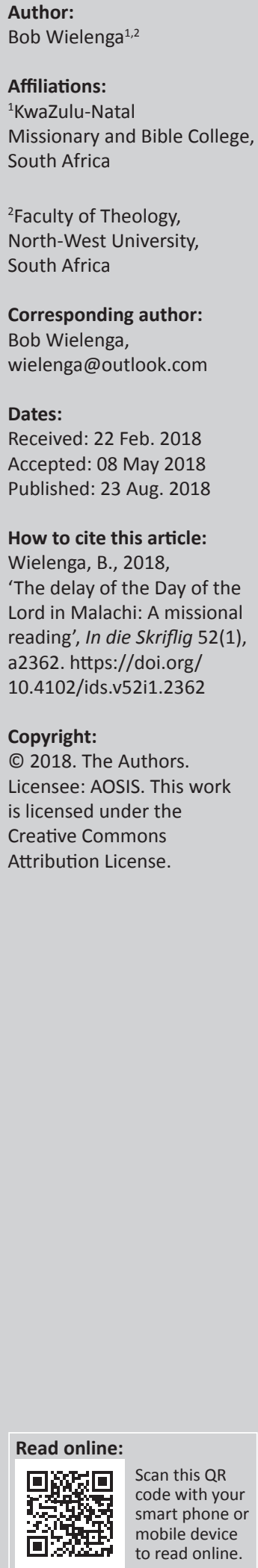

In this article, the missional significance of the delay of the Day of the Lord in the postexilic book of Malachi will be studied, employing a missional hermeneutic. First, the canon-historical meaning of the relevant eschatological texts in Malachi 3 will be established. Attention will be paid to the historical and literary context of Malachi in which his precursor, Joel, is pivotal. Second, the New Testament appropriation of Malachi 3 in Matthew's Gospel is assessed. To conclude, a proposal how Malachi's motif of the delay of the Day of the Lord can best be missionally re-employed in the present time, will be presented. Hence, apart from a brief note on missional hermeneutics, the missional origin of the text of Malachi, the missional motivation for the delay and the role of the Day of the Lord in modern missiology will be studied.

\section{Introduction}

Bible and mission is not the first topic that comes to mind when reading the book of Malachi. Apart from Malachi 1:11, 14, ${ }^{1}$ where it is said that God is a mighty King over the nations, not much is found in this mid-5th century BCE text that looks useful in a narrative about Bible and mission. It gives the impression of a more inward-looking book, concerned with the internal affairs of the postexilic Second Temple community in the Persian province of Yehud. It is much about a pure temple cult, priests properly observing their temple duties, marriage and divorce within the temple community, and several social malpractices found in the economically depressed and politically oppressed population, struggling with their ethnic identity. Whatever their relevance for the present-day Christian community of faith, missionally relevant they do not seem to be. This article wants to investigate the issue of the missional significance of Malachi, focusing on his use of the motif of the Day of the Lord, introduced by the prophet, Joel, in the postexilic prophetic discourse.

First, the Malachi text is hermeneutically studied in its own historical and canonical context. Canon-historical hermeneutics are applied here (McConville 2001:134-157; Wielenga 1994:226-232). The final texts, as they appear in the Old Testament, are read historically (with the grammatical-historical method), that is, moving forward from the Old Testament towards the New Testament, before reading backwards from the New Testament towards the Old Testament. The meaning of Malachi should be established first in his own historical context before its appropriation in the New Testament can be considered (Scholtz 2016:8). Second, this backwards reading is applied in studying the delay of the Day of the Lord in the Gospel tradition of Matthew. Third, the missional application of this motif in the present ecclesiastical context asks for a missional hermeneutic which will be introduced in the relevant section. This investigation aims particularly at elucidating the missional significance of the delay in the coming of the Day of the Lord.

\section{The Day of the Lord in Malachi}

As the last part of The Book of the Twelve, ${ }^{2}$ Malachi's handling of the Day of the Lord motif (Ml 2:17-3:7a, 13-21) stands in the tradition of his predecessors among whom the postexilic prophet, Joel, plays literary and thematic a pivotal role (Nogalski 2017; Sweeney 2000). ${ }^{3}$ Mention should also be made here of the influence of the scribal prophecy of 3 Isaiah on Malachi, composed

\footnotetext{
1.See Hill (1998), Snyman (2015), Viberg (1994) and Weyde (2000) for the discussion about the hyperbolical or (non-)eschatological interpretation of these verses.

2.The volume of literature on the Book of the Twelve (the Twelve onwards) is still expanding (see e.g. Boda 2017; Fabry 2016; Leuchter 2014; Nogalski 2007; 2017; Schart 2017; Sweeney 2000). For critical treatments of the concept, see Ben Zwi (1996), Childs (2003) and 2014; Nogalski 2007; 2017; Schart 2017; Sweeney 2000). For critical treatments of the conce
Troxel (2015). See Hwang (2014) for a discussion of the Missio Dei concept in the Twelve.

3.For the dating of the book of Joel, see apart from Nogalski (2017) also Assis (2011a), Cook (1995:167-170; 2003:106-108), Dillard
} (1992), Myers (1962), Pettus (1992). For the dating of Malachi's book, see Snyman (2015:1-3) and Wielenga (2016). 
as it is in the same cultural milieu in the Persian province of Yehud as Malachi in the mid-5th century BCE. One could also point to thematic links with Zechariah, but space constraints prevents them from being taken into consideration (see, however, Wielenga 2016). The pre-exilic Day of the Lord traditions, as in Amos 5:18-20 or in Zephaniah 1:7-18, are also not included in this investigation.

In this section, Malachi's own perspective on the Day of the Lord in 2:17-3:7a and 3:13-21, will be studied against the background of Joel's prophecy. This will lay the foundation for its appropriation in the New Testament and for its reemployment in the missional ministry of the current Christian community of faith. First, a short overview will be given of the social and spiritual condition of the postexilic Jewish people in their sparsely populated and geographically diminished homeland which gave rise to the judgement preaching of Malachi. Second, a summary of Joel's treatment of the Day of the Lord motif will follow next: it will provide the literary context for the discussion of the two images of divine judgement, refiner's fire and burning furnace, used in Malachi 3. This section ends with a theological assessment of Malachi's message of the Day of the Lord, focusing especially on the motif of its delay.

\section{Malachi's time}

The socio-economic situation in Yehud was dire. Natural calamities such as locust plagues and droughts ravaged the agrarian subsistence economy (Jl 1:4-7; Ha 1:6, 9-11; 2:15-17; Ml 3:10-11). The population numbered at most 20000 to 30000 people and was vulnerable to the threat of external and internal enemies. Heavily taxed by their Persian overlords, they had also to cope with the costs of the upkeep of the occupation troops (Lipschitz 2003:323-376; Vandenhooft 2003:235-262).

The temple in Jerusalem had been rebuilt and the cult restored since 515 BCE. However, Malachi's critique of the cult and its officials was fierce (Ml 1:10). The problems addressed by him rose from the decline of the cult in the temple where God was supposed to dwell (Ha 1:2-9; Boda 2017:107-126). Spiritually, the remnant population of Israel was in a crisis, disillusioned and disappointed by their circumstances which they ascribed to a God not interested in what was happening to his own people (Ml 2:17). The templecentred eschatological fervour, ignited by Haggai and Zechariah, and confirmed by 3 Isaiah, had long died down (Wielenga 2016:2).

As can be expected from a book that was included in the Twelve (Nogalski 2015:213-221; Pettus 1992:102-175), the prevalent faith tradition, found in Malachi, was of a covenantal nature (O’Brien 1990:85-107; Weyde 2000:37-47). Two breaches of the covenant are addressed in Malachi (Snyman 2015:122-123): the vertical one undermining the relationship with the God who had sovereignly established the covenant with his people (Ml 1:2-5; 2:6-9), and the horizontal one breaking up the covenant people by marrying outside the temple community (Ml 2:10-16). The coherence of God's people was under threat by this twofold breach of the covenant that had its origin in a deep-seated spiritual apathy (Ml 3:14), born out of the presumed delay of the fulfilment of the eschatological promises made in 520 BCE by Haggai.

\section{Malachi's precursor Joel}

The introduction of divine judgement in Malachi, to be effectuated on the Day of the Lord, followed the postexilic prophetic tradition that found its most powerful representative in Joel. His book is structured around the Day of the Lord as the day of judgement against Israel (J1 2:11), but also against the nations (J1 3:2), with a promise of a glorious Zion-centred future beyond judgement, already starting in the present for those among God's people who feared his name (Jl 2:32; 4:18-21), but with a promise of ultimate destruction for God's enemies (Jl 4:14-15), including those of his own people who would not repent and turn back to him in compliance with the obligations of the covenant as stipulated in Deuteronomy 28-30. ${ }^{4}$ A detailed investigation in Joel's Day of the Lord theology falls outside the scope of this article. It will rather limit itself to some summarised remarks to sketch the background of its appropriation by Malachi.

The concept of divine judgement to be effectuated on the Day of the Lord (Jl 1:15; 2:11,30-32; 3:1-21) came to prominence in the prophetic tradition (Nogalski 2007) and is coloured in Joel by a proto-apocalyptic imagination (Cook 1995:171). It refers to the imminent and to the ultimate intervention of God into this world on behalf of his people who have returned to him (Jl 2:18-19; 3:5) with, as reverse side, the destruction of those who have opposed him as well as the hostile nations and the unrepentant among his own people. One can distinguish between two perspectives on the Day of the Lord in Joel. ${ }^{5}$

The first perspective is historical in nature. It refers to a theophanic intervention in the space-time history of postexilic Yehud (J1 1:15) that soon will occur, as could be read from the 'sign of the time' - the harbinger of the imminent Day of the Lord: the extraordinary locust plague and subsequent drought (Jl 1:2-12), eventually followed by invading enemies from the North (Jl 2:1-11), that ravaged the countryside and threatened the basic necessities of life (Dt 28:38-40, 45; Dillard 1992:266). ${ }^{6}$ On that Day, God as judge would target his people for their covenantal faithlessness to the obligations, set by him for their own benefit (Dt 28:1-15;31:16-19; cf. Lv 26:1-13). In the early postexilic era, the threat of an invading enemy,

4.The literature on Joel and the Day of the Lord theology is extensive (see e.g. Pettus 1992; Sweeney 2003; Toffelmire 2014; Nogalski 2007; 2017).

5.What is intended here is not two temporally separated days. Proto-apocalyptic images should not be misconceived as literal descriptions of historical realities. Cook (2003:45,63) emphasises the anti-historicist, symbolic language employed in Cook (2003:45, 3 ) emphasises the anti-historicist, symbolic language employed in (proto-) apocalyptic literature. This literature employs a temporal and spatia historical framework to describe the eschatological revelation of God (Block
2006:

6.Pettus (1992:150), among others, understands Joel 2:1-11 as a reference to a real enemy, an intensification of the covenant curses as spelled out in Deuteronomy 28:49-52 in case repentance did not happen. 
as part of the promised punishment (Jl 2:1-11; Dt 28:45-50, 63-68), could be easily envisaged by Joel's audience and reapplied to their own historical context (Childs 1959:187198; Pettus 1992:142-145).

But because of God's 'zeal' for his land and its people, (Jl 2:18; Pettus 1992:154), alluding to Exodus 34, there was a way to avert this Day, consistent with the deuteronomic tradition (Dt 30:9): their wholehearted return to God expressed in a revitalised fidelity to their covenant obligations (Jl 1:13; 2:13-14). The blessing of the fields' fertility had already materialised (Jl 2:19-26) as a sign of hope beyond judgement. The Day of the Lord could be turned around from a Day of judgement into a Day of restoration of the fortunes of the faithful ones - a remnant of the people that came through judgement, acknowledging God for whom he truly is (J12:27). The differentiation among the people between seekers and forsakers of God's name (Is 65:8-16), can also traced back in Joel. ${ }^{7}$

The second perspective on the Day of the Lord is protoapocalyptic by nature (Cook 1995:167-210). One could say that, in the second part of Joel (J1 3-4), the historical Day of the Lord is intentionally reconfigured into the ultimate Day that would definitely occur at an unknown moment in the eschatological future, concluding space-time history. ${ }^{8}$ This rise of the apocalyptic imagination in prophetic eschatology, as can be observed in Joel 3-4, originated from the centre of the postexilic Second Temple community ${ }^{9}$ where a scribal circle around a prophet such as Joel was at work to unify his audience around the sacred teachings transmitted through Pentateuchal and prophetic oral and written sources. The natural calamities of the day blinded the people to the divine presence at work in their physical world and made them despair of the temple-centred eschatological promises made by someone like Haggai (Ha 2:6-9, 20-23) in 520 BCE (Wielenga 2015). At the same time, though, they were also blind to the spiritual background of the crisis, located by Joel in their covenantal unfaithfulness (J1 2:12-14). ${ }^{10}$

Joel's response was to point them to what had already happened as fruit of their repentance (Jl 2:18-19), ${ }^{11}$ while, simultaneously, focusing their hearts and minds on the ultimate restoration of their fortunes on the coming Day of the Lord when all possible threats against them would be 7.Theologically, one could point here to the influence of the deuteronomic covenant
concept: the covenant, unilaterally established by God, is bilaterally functioning,
that is, it assumes human co-operation (Wielenga 1998). It is all about divinehuman correlations that determine the course of history (Koch 1990:5).

8.One can distinguish between prophetic and apocalyptic eschatology, but not separate each from another (see Grabbe \& Haak 2003; Wielenga 2015:6; Allen 1990:21

9.In this article, Cook (1995; 2003; cf Sweeney 2003:167-178) is followed and not Hanson (1975) who advocated a socially peripheral location for apocalyptic literature (Redditt 1992:225) written by priestly groups opposing the central, hierocratic Zadokite priesthood embedded in the temple cult on Mount Zion (Allen 1990:17).

10.Sins are not mentioned in Joel (Talstra 2014:324-325), but it is very unlikely that the sin of covenant unfaithfulness was not assumed in a text versed in the deuteronomic traditions.

11.The verbal tenses in Joel 2:18-19 should be understood as imperfecta, indicating that God had already started to show mercy to his people who repented and returned to covenantal fidelity in line with Deuteronomy 28-30 (Troxel 2013:78-83). eliminated (Jl 4:1-3, 9-17) and they would live in God-given peace in an abundantly affluent environment $(3: 5 ; 4: 18)$. The ultimate Day would be one of destruction for God's enemies, but also one of restoration for God's people; only, it would be a remnant of the people that would pull through divine judgement on the ultimate Day of the Lord: those who had received God's Spirit and called upon his name (Jl 3:1-5). ${ }^{12}$ The prophet offered as encouragement that they would be heirs of the eschatological restoration of creation (Allen 1990:22) of which the already returned fertility of their fields was a first fruit of the harvest to come. ${ }^{13}$

Summarising Joel's Day of the Lord teaching, Allen (1990:24) calls it an expression of pastoral theology. The announcement of imminent and ultimate judgement on the Day of the Lord is used as a wake-up call to lament and repent in the Lord's presence, and so to avert the looming judgement that was already afflicting them through the natural calamities occurring among them. Divine judgement is, for Allen, not an inevitable fate that just happens, but it is a state of affairs that can be averted if the right response to the crisis is given. Nevertheless, as expressed in Joel 4:18-21, the ultimate future - free of evil and full of God's glory - cannot be jeopardised by human response and will not be revoked by God.

The distinction, made in Joel, between the imminent and the ultimate Day of the Lord should be noted (see footnote 5 above). It is not about two different days, temporally separated from each other. It is an apocalyptic image, symbolically referring to one and the same day located somewhere in space-time history, looked at from two different perspectives: the imminent, historical one and the apocalyptic, ultimate one. The first perspective shows that divine judgement can be averted; the second one that it is irrevocable. Eschatological restoration and destruction are reverse sides of each other, held together in covenantal tension ${ }^{14}$ by an eminently righteous God for whom mercy and justice are not in contradiction with each other, but strengthening each other (Peels 1992:250).

\section{The refiner's fire in Malachi 2:17-3:7a}

The people's complaint that God is not faithful to his covenant promises ( $\mathrm{Ml} 2: 17$ ) is dispelled in Malachi 3:6 ${ }^{15}$ with the assurance that God's attitude towards them did not change. Apart from blessings, curses had also been promised in case of covenantal unfaithfulness (Ml 3:6; Dt 28-30; Lv 26). The announcement of the sudden arrival of the Lord at his dwelling place on Mount Zion (Ml 3:1b) is intended to create

12. For a comprehensive, accessible introduction to a biblical theology of repentance, see Boda (2015); for the concept of divine enablement for repentance, see Boda (2015:158-159, 189).

13.Also, in Haggai 2:3-7, a small beginning (temple foundations) received an apocalyptic-eschatological ending, centred on God dwelling in the fully reconstructed temple on Mount Zion (Wielenga 2015:6-7).

14.The tension between eschatological restoration and destruction is an integral part of the two-sided covenantal relationship between God and his people with its promises both of blessing and curse (Dt 28-30). Drs C.J. (Kees) Haak, Theological University Kampen, Netherland, suggested the term covenantal tension to me.

15.Snyman's demarcation (2015:125-129) of this section is followed here. 
fear; first among the temple staff, the sons of Levi (Ml 3:3) with whom God had concluded a covenant (Ml 2:4). The judgement is not yet definite as Malachi 2:2 indicates: If you do not listen ..., if you do not take it to heart ..., addressing the priests (Ml 2:1; Boda 2017:110). The image of divine judgement as refiner's fire (Ml 3:2-4; Zch 13:9), underscores this observation. The goal of a silversmith was to produce an unblemished product. God's purpose with his judgement was to restore the covenant with Levi (Ml 2:4; 3:3-4) and so a pure temple cult, up to Mosaic standards, as starting point for the spiritual turnaround of the people (Dt 33:8-10). Despite their perpetual condition of covenantal unfaithfulness (Ml 3:7a), they were not yet consumed (Snyman 2015:142), ${ }^{16}$ but still able to return to the God of their fathers (Ml 3:6), confessing their sins (Ml 3:5). Judgement on the Day of the Lord could be averted. This is consistent with the message of Joel with its allusion to Exodus 34 in Joel 2:18. The same theological concept, supporting the argument in this passage, can be found in Malachi 1:2-3 and 3:17 - that of God's covenantal love for 'the sons of Jacob', a reference to their election of old.

This concurs with the announcement that God had already sent ahead his messenger ( $\mathrm{Ml} 3: 1 \mathrm{a})$ who would prepare his forthcoming arrival as judge (Snyman 2015:130-132; Wielenga 2016:6). The time of judgement has been announced, but a timetable is not given in typical proto-apocalyptic fashion ('sudden') (Ml 3:1b). The time of grace was ushered in synchronous with the proclamation of the time of judgement. Alluding to Isaiah 40:3 and 57:14-21, the preparation work of the messenger can be understood as a warning and wake-up call, first for the temple staff, but subsequently for the whole remnant people in Yehud. Heeding the message of the messenger would open a path through judgement towards restoration beyond.

There is no scholarly consensus around the identity of the messenger. In this article, the option of a non-messianic, prophetic figure is followed (Wielenga 2016:6-7). ${ }^{17}$ Malachi himself could have been a model of such a messenger and his ministry (considering that his name means 'my messenger'), causing a delay in the arrival of the Day of the Lord with its judgement, creating space for divine grace and covenantal penitence and return. In the redactional attachment to the book (Ml 3:23-24; Assis 2011b), the editors have equated the messenger of Malachi 3:1a with the coming Elijah (Chapman 2000:139-145; also see Snyman 2015:190191 for a different view), ${ }^{18}$ a decision that, subsequently, has been confirmed in the New Testament in its identification of John the Baptist as the eschatological Elijah (Lk 1:76; Mt 11:14; Jn 1:19-27).

16.See Jeremiah $5: 18,30: 11$ and $46: 28$ for a pre-exilic reference to this type of statement of faith ('not yet consumed').

17.For the non-messianic option, see Snyman (2015:122, 130-135), and Bauckham (2008:330-335). De Haan and Hlela (2016:60-63), following Van der Woude (1982:131-134), opt for one angel-messenger in Malachi 3:1, referring to three different aspects of his work.

18.The task the eschatological Elijah must perform according to Malachi 3:24 (Van de Woude 1982:159) and that of the messenger in Malachi 3:1a, are presupposing each other.

\section{The burning furnace in Malachi 3:17-21}

Fire in a burning furnace will leave nothing behind but ash (Ml 3:21). It calls up the image of ultimate destruction. It is used in the context of arrogant refusal by the majority of the people to face the consequences of their negligence of the covenant and of their subsequent accusation of God for the deplorable conditions that are of their own making. Different from Joel, Malachi's Day of the Lord preaching did not target the hostile nations; rather, only God's own people were marked out for judgement. God's ultimate intervention would bring separation between those who feared the Lord and revered his name, and those who did not, beyond judgement, care (Ml 3:14-15). The first ones would be remembered ${ }^{19}$ and will enjoy eschatological peace beyond judgement, basking in the sun of righteousness which will rise with healing in its wings (Snyman 2015:172-175; Weyde 2000:373). For those among his own people who persistently refused to repent in penitence and return to a life compliant with the Law of Moses (Ml 3:22), the Day would be like a burning furnace: no hope for them beyond judgement (Snyman 2015:171-172). Joel's differentiation among God's people between a minority and a majority voice, can also be observed in Malachi.

The ultimate Day of the Lord is coming. In Malachi its description is less apocalyptically coloured than in Joel, but its expectation is not less realistic. In Malachi, just as in Joel, the pastoral motivation for his eschatological preaching must be noted. Irrevocable as the coming of the ultimate Day of the Lord may be, it is not a fate that, come what may, will happen. The historical imminent and the apocalyptic ultimate perspectives are coalescing in their pastoral intention: to activate a wholehearted return to God and a law-compliant life in expectation of the definite restoration of justice beyond final judgement (Ml 3:20).

This sole concentration on the restoration of God's people themselves, was not fruit of an exclusivist concern in Malachi's discourse. Consistent with other postexilic prophetic voices, this pastoral initiative would have consequences in the world

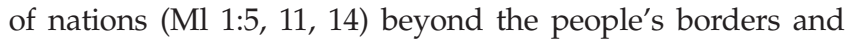
boundaries. The exclusion of the nations in Malachi is therefore not an expression of early Jewish particularism (Wielenga 2016:8). It rather is a matter of priorities: in this particular situation, the divine message addressed the serious threat of the dissolution of the covenant people of God with possible repercussions for God's eschatological agenda with his world as expounded in the meta-narrative of the canonical Old Testament Scriptures (Green 2016:196-198; Wielenga 2016:8; Wright 2016:107-123)..$^{20}$

\section{Theological assessment}

Malachi's concentration on divine judgement for God's own people on the Day of the Lord, suggests a particular trend in

19.Nogalski's equation (2007:132) of the Book of remembrance, Malachi 3:16 with the Twelve is unfounded (cf. Leuchter 2014:256-257). See Snyman (2015:167) for a careful interpretation of the expression.

20.The same charge of Jewish particularism is incorrectly levelled against EzraNehemiah (Wielenga 2013). 
the postexilic eschatological discourse that distinguishes him from Joel. From Joel 4:9-21 (cf. Hg 2:6-9; Zch 14:6-19; Is $65: 17-25)$, one can conclude that the advent of the ultimate Day of the Lord has been definitely decided upon by a God sovereignly in control of history. Nevertheless, in Malachi, the fulfilment of this eschatological promise looks to be deferred by the spiritual crisis the people as temple community found themselves in. This necessitated the timeconsuming ministry of the messenger of Malachi 3:1a, preparing the people for divine judgement, and thus opening up the opportunity of penitential return to God. The deferral of the effectuation of divine judgement should therefore be seen in a positive light: it gives the afflicted people, the remnant of Israel, but also, by implication, the nations, the opportunity to avert judgement. Simultaneously, the delay of the promised restoration of eschatological justice, symbolised by the image of a rising sun with healing in its wings, will be perceived as a negative effect of the messenger's ministry. Fulfilment of the eschatological prophecy is going to take much longer than could possibly be apprehended, but it is given with the conditional character of those promises. Divine mercy, on the one hand, and divine justice, on the other, should be kept together in covenantal tension (Hays 2016b:102-106). The imminence of the Day of the Lord and its delay are not mutually exclusive.

Therefore, another aspect of Old Testament eschatology must be considered. As Hays (2016a:23-38) has stressed, the eschatological prophecies in the Old Testament are not futuristic predictions that are discharged without fail (cf. Kashow 2013:393-402; Tiemeyer 2005:340, 349). These prophecies are, first, conditional, and second, meant to activate the audience into a desired course of action. In the case of Malachi, the judgement discourse intended to motivate the people to repent of their sins and to return to a law-compliant life before God, waiting for the eschatological prophecies to be fulfilled. It is less about prognostication than about motivation (Strine 2016:39-58). The conditionality of the eschatological prophecies, rooted in the deuteronomic covenant traditions, implies that their fulfilment hardly ever happened in a straightforward, one-on-one way. A positive response to judgement prophecies meant that their intended purpose was realised. The reason for the judgement prophecy was, then, taken away; its intention was realised. In the fulfilment process, the responsibility of the covenant partner was included. Non-fulfilment could be, in this case, called (partial) fulfilment (Strine 2016:55-56). ${ }^{21}$

In conclusion, the possibility of a delay of the Day of the Lord is not mentioned in Malachi's dialogues with the people, but it is, nevertheless, a reality rooted in the covenantal relationship between God and his people. The delay of the ultimate restoration on the Day of the Lord and the consummation of history has, as its reverse side, the deferral of the destruction of all that opposes the God of Israel, the

21.The conditional fulfilment of eschatological prophecies touches on the doctrine of divine providence in, among others, Reformed theology (König 2002; 2003; Van
Wyk 2002), and in Eastern-Orthodoxy (Callaher \& Konstantinovsky 2016:147-174). Wyk 2002), and in Eastern-Orthodoxy
This article assumes König's position.
Creator and Lord of history. In this light, the partial fulfilments of the eschatological promises, as in Joel 2:18-19 or Malachi $2: 2$ and $3: 3-4,22$ should be understood as encouraging stepping stones in the direction of total fulfilment which is assured by the faithfulness of a sovereign God (Hays \& Ounsworth 2016:62-68).

\section{Malachi 3:23-24 in the New Testament: John the Baptist}

Because of space constraints, only the ministry of John the Baptist, the eschatological Elijah (Ml 3:23-24), will be studied within the gospel tradition, focusing on Matthew with his many apocalyptic motifs and symbols (Gurtner 2012:531, 544; Hagner 1985:53,60), paying special attention to the delay of the Day of the Lord.

In 1st century CE Judaism, the coming of the eschatological prophet, in accordance with Deuteronomy 18:18 or Malachi 3:23, was urgently awaited. Elijah who, at his death, bodily ascended straight into heaven (2 Kngs 2), was the designated candidate for a new eschatological ministry on earth (Ml 3:24). ${ }^{23}$ Even though John himself denied being Elijah redivivus (Jn 1:21), ${ }^{24}$ he was, beyond doubt, associated by Jesus and the Early Church with the Elijah of Malachi 3:23 whose ministry formed the model for John's own (Lk 1:17; Mt 11:14). Conformance ${ }^{25}$ with Malachi's prophecy justified John's ministry in all its scope and depth. He was the endtime prophet, inaugurating divine judgement on Israel on the ultimate Day of the Lord. Not even descending from Abraham would avert God's wrath from them (Is 63:16). Only repentance and penitential return to the God of their fathers, with a corresponding life style to prove it, could achieve that. In accordance with Malachi 3:1b, the Lord as judge had come in the person of Jesus of Nazareth. For John, the eschatological future had begun.

John's image of an axe already at the root of the tree, about to be burnt, refers to the ultimate judgement that he himself expected to happen in the near future. This is underscored by John's description of Jesus' work as baptising with fire (Mt 3:11-12; Lk 3:16-17; 12:49) that in this context is a clear indication of Jesus bringing divine judgement (Miller 2007:14-15). This concurs with the burning furnace image in Malachi 3:19. John refers to the other perspective on the Day of the Lord in Malachi 3:2-4, visualised in the image of a refiner's fire, by his announcement that Jesus would baptise with the Holy Spirit (Mt 3:11; Öhler 1997:59-61). The looming judgement could be averted by receiving the Lord who had come in the person of Jesus (Ml 3:1b). But John's exchange with Jesus, while in prison (Mt 11:2-19; Lk 7:18-30), makes

22.See Wielenga (2015:7) for this concept of partial fulfilment in Haggai.

23.For Elijah as prophet, ranked at the same level as Moses, see Chapman (2000:118123) and Wielenga (2016:8).

24.In Matthew 17:3, Elijah was present on the Mount of Transfiguration together with Moses. He and John were clearly not identical in the estimation of the Early Moses.
Church.

25.See Philips, Janse van Rensburg and Van Rooy (2012:7) for the concept of conformity in the use of the Old Testament by the New Testament. 
clear that he did expect a speedy execution of God's judgement without any delay with, as reverse side, the immediate advent of the final restoration of the repenting minority in a renewed world. He did not observe any acceleration in the fulfilment of the judgement prophecy since Jesus' arrival on the scene; just the opposite. Consequently, he doubted the veracity of Jesus' claims (Mt $4: 23 ; 5-7)$. That John's own ministry had already had a delaying effect, is not explicated in the text, but should be noted. It is given with the conditional character of the eschatological prophecy of Malachi 3:1a. John's ministry caused the prolongation of time needed for a response to his message - positively or negatively.

In his response (Mt 11:4-6; Lk 7:21-23), Jesus did not refute John's expectation of a final judgement on the ultimate Day of the Lord (Mt 11:20-24, cf. 13:49-50). But in conformance with the prophecy of Malachi, the ultimate Day of the Lord is deliberately deferred to an unspecified time in the future to create space for Jesus' own ministry of preaching and healing, erecting the signs of the messianic age to come (Is 35:1-10; 61:1; Mt 11:4-5) ${ }^{26}$ among which the mission to the nations is pre-eminent (Mk 13:10; Mt 24:14; BeasleyMurray 1990:46). The end will come beyond any doubt, but not yet. Time is, on the contrary, prolonged for the sake of the people - first the Jews and then the Gentiles - to receive the Lord (Ml 3:1b) who is, in the in-between times, not the divine judge, but, in the Early Church's reconfiguration, the divine Advocate (1 Jn 2:1).

Subsequently, this delay of final judgement also causes the ongoing suffering of those who were baptised by Jesus with the Holy Spirit (Mt 11:6, 28-30). The emphasis in Matthew is on the suffering for the sake of Jesus and his ministry (Mt $5: 10-12 ; 10: 24-28)$. Besides, the delay of the Day of the Lord, breaking in at the time that the Lord returns as divine judge, also presumes the protraction of evil and suffering in all spheres of life. The interim time is the time of grace and the time of suffering simultaneously, both a fruit of the gracious prolongation of the in-between time until a future date, known only to God (Mt 24:36, 42, 44; Ac 1:7).

In conclusion, the principle of conditional fulfilment of eschatological promises is at work in Matthew regarding the ministry of John the Baptist in conformance with Malachi 3. The time, allocated to the response of the audience to the preaching of John, Jesus, and later the disciples (Mt 28:16-20), should be taken seriously in the assessment of the eschatological delay. This whole process of delay does not jeopardise the divine consummation of history, portrayed with apocalyptic images in Joel, Haggai, Zechariah or 3 Isaiah, or Revelation. Rather, in this process, the interim time is urgently moving forward to its destined, imminent end, even though no sensible word can be said about its speed and its date. The perspective of imminence should encourage

26.These signs signified that with Jesus' advent, the age to come had already been inaugurated, encouraging the readers to await with patient impatience the consummation of that age (cf. the famous eschatological already or not ye distinction) within a covenantal framework that stresses the faithfulness of a sovereign God, but that of delay should activate his people, appealing to their covenantal responsibility.

\section{Malachi read missionally}

In this section, missional conclusions will be drawn from the preceding canon-historical investigation into Malachi's eschatological discourse and its appropriation in Matthew. First, a brief outline will be given of the missional hermeneutics employed in this article; second, the missional origins of Malachi will be pointed out; and third, the missional significance of the delay of the Day of the Lord in Malachi, as mediated by Matthew, will be elucidated.

\section{Missional hermeneutics}

The attempt to read Malachi missionally, flows from the premise that the Old Testament, just like the New Testament, is an inalienable part of the canon of the Scriptures of the Christian community of faith - the proper locus for a theological reading of the Bible with a missional hermeneutic (Bartholomew 2016:77-78; Goheen 2016:10; Wielenga 2010:709-711). Reading the Bible missionally, means to read it through a missional lens, that is, with mission as its central interest and goal (Bauckham 2016:28) ${ }^{27}$ In this article, mission is understood as missio dei (Van Rooy 2017) which must be distinguished from the missiones ecclesiae (Hwang 2014:167). ${ }^{28}$ One should not concentrate on what God's people are supposed to do, but on what God himself has decided to do. ${ }^{29}$ The missio dei concept refers to God as the One who moves through history from creation towards recreation - a history that should be qualified as redemptive since the human countermovement as described in Genesis 3. He works out his plan sovereignly in this history with, as its centre, the redemptive work of his incarnated Son Jesus Christ (missio dei). In the realisation of his goal for history, Revelation 21, he involves his chosen and covenanted people (missiones ecclesiae) (see Wielenga 1998:246-273). Three aspects of this movement through history can be distinguished (Bauckham 2016:31-36): the temporal, spatial and social of which, in this article, only the temporal aspect will be discussed, having a bearing on the missional understanding of Malachi's Day of the Lord theology as mediated by Matthew.

\section{Missional origin of Malachi}

Reading Malachi missionally as part of this canonical metanarrative, one is faced with the question why the Malachi text has been transmitted, even written down and included in the Twelve to become part of the Old Testament canon at all. It is

27.For an interesting example of missional reading of the Old Testament (Ex 15:1-18), see Russell (2017:151-158).

28.This is not to say that this lens is the only legitimate one through which to read the Bible (Bartholomew 2016:69-71). Missional hermeneutics is comprehensive, but not all-inclusive, just like mission is (Wielenga (1998:241-281). Haak (2017:159, 164-166, 171) calls his approach a missional-ecumenic hermeneutics, stressing $164-166,171)$ calls his approach a missional-ecumenic hermeneutics,
intercultural reading at its core with the gospel as interpretative matrix.

29. Here the difference between Old Testament and New Testament, concerning mission, should be mentioned. It often referred to with the terms centripetal and centrifugal (see also Bauckham 2016:34-36). 
the contention of this article that Malachi, as part of the Bible, is a product of the missio dei (cf. Wright 2016:109-110). The text has been conserved and transmitted to motivate and activate God's people to live out and articulate their understanding of God's revelation and redemptive actions in the world, strengthening them in times of crisis and calling them back to their original calling as his chosen and covenanted people (Gn 12:3; Ex 19:5-6; Dt 4:6-8). In this sense, Malachi shares in the missional character of the Bible; it is fruit of the same missional Source. The sorting out of the spiritual and corporate crises, addressed in Malachi, did not simply serve internal considerations of survival of the postexilic remnant population in Yehud. It was about their position as God's chosen and covenanted people in the bigger scheme of redemptive history. The spiritual revitalisation of God's people served the missional goal of God, dwelling among his people on Mount Zion in the reconstructed temple for the sake of the nations of the world (Boda 2015:154) which should be attracted to pilgrimage to Zion (Ha 2:6-9; Zch 14:16-18). This missional goal gave rise to Malachi. Without Israel's return to God, it could not have attracted the nations to worship God in Zion together with Israel. This insight is missionally significant in the present history of the Christian community of faith (Bosch 1991:137-138).

\section{Missional significance of Malachi}

Focusing now on the question of the missional significance of the delay of the Day of the Lord in Malachi, as confirmed by Matthew, first, the relationship between the messenger's ministry in Malachi 3:1a (with its parallel in Mt 3:1-2) and the mission mandate to the apostles as formulated in Matthew 28:16-20 will be considered (Fernando 2007:55; Wielenga 2002:111-119; 2009:15-19). Second, in conclusion, attention will be paid to the concept of the Day of the Lord with its divine judgement in the context of modern missiology (Bosch 1991).

\section{The missional motivation of the delay}

Mission, as defined in Matthew 28, focuses on making disciples out of all the nations, incorporating them in the new community through baptism and teaching them all that Jesus had commanded in Matthew 5-7, for instance. In conformance with Malachi 3:1a and Matthew 3:1-2, and Jesus' own earthly ministry, this ministry ${ }^{30}$ implicitly assumes the prolongation of time (Hagner 1994:60-61), prompted by the conditional character of eschatological prophecies as discussed above. Therefore, no crisis is hinted at in the New Testament around the delay of the Parousia, the suspension of final judgement and the stay of the arrival of the glorious age to come (Hagner 1994:62-69). The delay serves a missional goal, beneficial for humankind. In short, mission means the prolongation of the messenger's ministry of Malachi 3:1a post-Pentecost (Jn 16:5-11).

The deepest motivation for this delay has already been formulated by Joel and Malachi (Jl 2:18-19; Ml 1:2-5), and is confirmed by Jesus' words in John 3:16 or Paul's in 2 Corinthians 5:14. Mission is fruit of God's love for the world in Jesus Christ which compels the church to get involved in the missio dei (see also 2 Pt 3:9). However imminent the Day of the Lord may be and urgently awaited amid the suffering for the sake of Christ and the protraction of evil in the world, no deadline is given for the work to be finished. The delay of the Day of the Lord is an expression of God's mercy which the Christian community should rejoice about and make missionally the most of. ${ }^{31}$

For that reason, in Matthew 24:14, mission is mentioned among the signs of the time that matter (Beasley-Murray 1990:47-50). Among all the false alarms around the date of the Parousia, raised by false prophets, one should focus on the worldwide missional ministry as the pre-eminent portent of the Parousia, affirming that calculations about the date and time are futile (Mt 24:36, 42,44). One should rather rejoice about the in-between time of grace entrusted by a merciful God, sustained amid suffering and evil by the living Christ who is among his people through the Spirit (Mt 28:20). Mission is the single most important agency causing the delay of the Day of the Lord. ${ }^{32}$

\section{Paradigm lost: divine judgement}

In modern missiology, divine judgement is not an issue that receives much attention. Towner (1995:99-113), discussing David Bosch's influential study (1991) of paradigm shifts in the theology of mission, observes that Bosch does not include in his biblical overview the Gospel of John with its dual perspective on 'the world'. The world is not only loved, but also judged by God, depending on the response given to the ministry of Jesus Christ, God's beloved Son, through whom the glorious age to come has been inaugurated, but whose advent, simultaneously, initiated the reverse side of that age - final judgement on the ultimate Day of the Lord (Jn 3:16-21; Rm 1:18-32; Thiselton 2016:81-91). Towner (1995:116) speaks of a paradigm lost in Bosch's discussion of the missionally relevant biblical traditions. This concurs with Bosch's treatment of Luke 4:18-19 (1991:110-113) where he stresses that the divine vengeance, in Isaiah 61:2 the reverse side of the favourable year of the Lord (Peels 1992:133-137) is intentionally 'superseded'.$^{33}$ One can agree with Bosch that certain vengeful notions about divine wrath upon the nations, abounding in 1st century CE Judaism, are repudiated by Jesus. Nonetheless, the execution of divine judgement on those who turn against God's gift of love in Jesus Christ to a world lost in darkness (Jn 1:5-12), is deferred and can be averted, but is certainly not superseded. As Peels (1992:248250) argues, in a study about the vengeance (nqm) of God in the Old Testament, God's vengeance or judgement is not in

31.The prayer for an urgent return of Christ amid suffering remains valid. Again, the covenant is the framework within which both the needed advent and the granted delay are kept together in tension.

32.One finds in Matthew, too, the dual perspective on the imminent and ultimate eschatological blessing and judgement. In Matthew 24, they are correlated (Hagner 1994:56-58).

33.See also Bosch's treatment of 'comprehensive salvation' (1991:393-400) in which the classic notion of justification of the godless by faith has been side-lined as Anselmian satisfaction theory (p. 399) 
contradiction to his love (Thiselton 2016:82). They are the reverse sides of each other. In the end, God's vengeance serves his love. Final judgement serves the goal of the missio $d e i$, the restoration and renewal of a creation gone wrong, in which all people, Jew and Gentile, together will bring honour and glory to God (Phlp 2:10-11) in the new Jerusalem without a temple (Rv 21:22). Final judgement signifies that evil, death, pain and crying will not be found in the age to come (Rv 21:4, 8). This will be achieved through judgement on the ultimate Day of the Lord.

From the missional ministry of the Christian community of faith, a careful and balanced approach is required towards this theme of divine vengeance and judgement, but it should not be deleted from its missional agenda. However, threatening speculations with violent phantasies about eternal damnation and hell (LeHaye and Jenkins) should not be part of this agenda. Biblical images, referring to these realities, are apocalyptic notions that are not intended to literally describe what is beyond human comprehension. They are meant to confront the world with the seriousness and consequences of the choice for or against Jesus Christ as the eschatological Lord of Malachi 3:1b. ${ }^{34}$ Without disparaging the reality of divine judgement, the focus in missional ministry is, on its reverse side, God's will to restore creation and to renew all its inhabitants to the glory of its Creator, King and Redeemer.

\section{Conclusion}

This article attempted to read the postexilic minor prophet, Malachi, missionally, focusing on the delay of the Day of the Lord. The conclusion that this motif is missionally relevant also for the present-day Christian community of faith, should convince Bible scholars that a missional hermeneutic occupies a legitimate place among the Bible reading tools of the profession.

\section{Acknowledgements Competing interests}

The author declares that he has no financial or personal relationships which may have inappropriately influenced him in writing this article.

\section{References}

Allen, L., 1990, 'Some prophetic antecedents of apocalyptic eschatology and their hermeneutic value', Ex Auditu 6, 15-28.

Assis, E., 2011a, 'The date and meaning of the book of Joel', Vetus Testamentum 61 163-183. https://doi.org/10.1163/156853311X564787

Assis, E., 2011b, 'Moses, Elijah and the messianic hope: A new reading of Malachi 3:22-24', Zeitschrift für alttestamentliche Wissenschaft 123, 207-220. https://doi. org/10.1515/zaw.2011.013

Bartholomew, C.G., 2016, 'Theological interpretation and a missional hermeneutic', in M.W. Goheen (ed.), Reading the Bible missionally, pp. 68-85, Wm. B. Eerdmans, Grand Rapids, MI.

Bauckham, R., 2008, The Jewish world around the New Testament, Mohr Siebeck, Tübingen.

Bauckham, R., 2016, 'Mission as hermeneutic for Scriptural interpretation', in M.W. Goheen (ed.), Reading the Bible missionally, pp. 28-44, Wm. B. Eerdmans, Grand Rapids, Ml.

34.See Van der Kooi and Van den Brink (2017:711-759) for a balanced treatment of the theme of heaven and hell from a systematic point of view.
Beasley-Murray, G., 1990, 'The vision on the mount: The eschatological discourse of Mark 13', Ex Auditu 6, 39-52.

Ben Zwi, E., 1996, 'Twelve prophetic books or the Twelve: A few preliminary considerations', in J.W. Watts \& P.R. House (eds.), Forming prophetic literature: Essays on Isaiah and the Twelve in honour of J.D.W. Watts, pp. 125-156, Sheffield Academic Press, Sheffield, (JSOT SS 235).

Block, D.I., 2006, 'Preaching Old Testament apocalyptic to a New Testament church', Calvin Theological Journal 41, 17-52.

Boda, M.J., 2015, 'Return to me'. A biblical theology of repentance, InterVarsity Press, Downers Grove, IL.

Boda, M.J., 2017, Exploring Zechariah. Volume 1. The development of Zechariah and its role within the Twelve, SBL Press, Atlanta, GA.

Bosch, D.J., 1991, Transforming mission. Paradigm shifts in theology of mission, Orbis Books, MaryKnoll.

Callaher, B. \& Konstantinovski, J.S., 2016, 'Divine possibilities: The condescension of God and the restriction of divine freedom', in C.M. Hays (ed.), When the Son of man didn't come. A constructive proposal on the delay of the Parousia, pp. 147174, Fortress Press, Minneapolis, MN.

Chapman, S.B., 2000, The law and the prophets: A study in Old Testament canon formation, Mohr Siebeck, Tübingen, (Forschungen zum Alten Testament, 27)

Childs, B.S., 1959, 'The enemy from the North and the chaos tradition', Journal of Biblical Literature 78(3), 187-198. https://doi.org/10.2307/3264964

Childs, B.S., 2003, 'Critique of recent intertextual canonical interpretation', Zeitschrift für alttestamentliche Wissenschaft 115, 173-184. https://doi.org/10.1515/ zatw.2003.010

Cook, S.L., 1995, Prophecy and apocalypticism: The postexilic social setting, Fortress Press, Minneapolis, MN.

Cook, S.L., 2003, The apocalyptic literature, Abingdon Press, Nashville, TN.

De Haan, M.J. \& Hlela, P.T., 2016, Amazwi omprophethi omncane uMalakhi: A commentary on the book of Malachi in isizulu, Clusters Publications, Pietermaritzburg.

Dillard, R.B., 1992, 'Joel', in T.E. McComskey (ed.), The minor prophets Hosea, Joel, Amos, Baker Bookhouse, Grand Rapids, MI (An exegetical and expository commentary, 1)

Fernando, K., 2007, 'Mission: A problem of definition', Themelios 33, 1, 46-59.

Fabry, H.-J., 2016, 'The Book of the Twelve: Minor prophets - major theologies', Ephemerides Theologicae Lovanienses 92(4), 641-654.

Goheen, M.W., 2016, 'A history and introduction to a missional reading of the Bible', in M.W. Goheen (ed.), Reading the Bible missionally, pp. 3-27, Wm. B. Eerdmans, Grand Rapids, MI.

Grabbe, L.L. \& Haak, R.D. (eds.), 2003, Knowing the end from the beginning: The prophetic, the apocalyptic and their relationship, Clark International, London.

Green, J.B., 2016, 'Reading James missionally', in M.W. Goheen (ed.), Reading the Bible missionally, pp. 194-212, Wm. B. Eerdmans, Grand Rapids, MI.

Gurtner, D.M., 2012, 'Interpreting apocalyptic symbolism in the Gospel of Matthew', Bulletin for Biblical Research 22(4), 525-545.

Haak, C.J., 2017, 'Bijbellezen in missionair-oecumenisch perspectief. Lezen met het evangelie als interpretatiematrix', in A. de Bruijne \& H. Burger (reds.) Gereformeerde hermeneutiek vandaag. Theologische perspectieven, pp. 159-180, Uitgeverij De Vuurbaak, Barneveld (TU-bezinningsreeks, 18).

Hagner, D.A., 1985, 'Apocalyptic motifs in the Gospel of Matthew: Continuity and discontinuity', Horizons of Biblical Theology 7, 53-82. https://doi.org/10.1163/ 187122085X00105

Hagner, D.A., 1994, 'Matthew's eschatology', in T.E. Schmidt \& M. Silva (eds.), To tell the mystery. Essays on New Testament eschatology in honour of Robert H. Gundry, pp. 49-71, JSOT Press, Sheffield.

Hanson, P.D., 1975, The dawn of apocalyptic, Fortress, Philadelphia, PA.

Hays, C.M., 2016a, 'Prophecy: A history of failure?', in C.M. Hays (ed.), When the Son of Man didn't come. A constructive proposal on the delay of the Parousia, pp. 23-38, Fortress Press, Minneapolis, MN

Hays, C.M., 2016b, 'The delay of the Parousia: A traditional and historical-critical reading of Scripture: Part 2', in C.M. Hays (ed.), When the Son of man didn't come. A constructive proposal on the delay of the Parousia, pp. 79-107, Fortress Press, Minneapolis, MN.

Hays, C.M. \& Ounsworth, R.J., 2016, 'The delay of the Parousia: A traditional and historical-critical reading of Scripture: Part 1', in C.M. Hays (ed.), When the Son of Man didn't come: A constructive proposal on the delay of the Parousia, pp. 59-78, Fortress Press, Minneapolis, MN.

Hill, A.E., 1998, Malachi, Doubleday, New York (Anchor Bible Commentaries, 25D).

Hwang, J., 2014, 'My name will be great among the nations: The missio dei in the Twelve', Tyndale Bulletin 65(2), 161-180.

Kashow, R.C., 2013, 'Zechariah 1-8 as a theological explanation for the failure of prophecy in Haggai 2:20-23', Journal for Theological Study 64(2), 385-403. https://doi.org/10.1093/jts/flt097

Koch, K., 1990, 'Damnation and salvation: Prophetic metahistory and the rise of eschatology in the book of Isaiah', Ex Auditu 6, 5-14.

König, A., 2002, God, waarom lyk die wêreld só? Kan ons sê: 'God is in beheer?', Lux Verbi.BM, Wellington.

König, A., 2003, 'Diskussie: Van Wyk se bespreking van my boek “God, waarom lyk die wêreld so?"', In die Skriflig/In Luce Verbi 37(4), 735-740. https://doi.org/10.4102/ ids.v37i4.491 
Leuchter, M., 2014, 'Another look at the Hosea/Malachi framework of The Twelve', Vetus Testamentum 64, 249-265. https://doi.org/10.1163/15685330-12341149

Lipschitz, O., 2003, 'Demographic changes in Judah between the 7th and 5 th centuries BCE', in O. Lipschitz \& J. Blenkinsopp (eds.), Judah and the Judaeans in the NeoBabylonian period, pp. 323-376, Eisenbrauns, Winona Lake, IN.

McConville, J.G., 2001, 'Biblical theology: Canon and plain sense', Scottish Bulletin of Evangelical Theology 19(2), 134-157.

Miller, D., 2007, 'The messenger, the Lord, and the coming judgment in the reception history of Malachi 3', New Testament Studies 53(1), 1-16. https://doi.org/10.1017/ S002868850700001X

Myers, J.M., 1962, 'Some considerations bearing on the date of Joel', Zeitschrift für alttestamentliche Wissenschaft 74(2), 177-195. https://doi.org/10.1515/ zatw.1962.74.2.177

Nogalski, J.D., 2007, 'Recurring themes in the Book of the Twelve: Creating points of contact for a theological reading', Interpretation 61(2), 125-136. https://doi. org/10.1177/002096430706100202

Nogalski, J.D., 2015, 'Presumptions of "covenant" in Joel', in J.R. Bautch \& G.N. Knoppers (eds.), Covenant in the Persian period: From Genesis to Chronicles, pp. 211-228, Eisenbrauns, Winona Lake, IN.

Nogalski, J.D., 2017, 'Joel as literary anchor for the book of the Twelve', in J.D. Nogalsk (ed.), The Book of the Twelve and beyond: Collected essays of J.D. Nogalski, pp. 137-156, SBL Press, Atlanta, GA.

O'Brien, J.M., 1990, Priest and Levite in Malachi, Scholars Press, Atlanta, GA. (SBL Dissertation Series, 121).

Öhler, M., 1997, Elia im Neuen Testament: Untersuchungen zur Bedeutung des alttestamentlichen Propheten in Frühen Christentum, De Gruyter, Tübingen. (Beihefte zur Zeitschrift für die neutestamentliche Wissenschaft).

Peels, H.G.L., 1992, De wraak van God. De betekenis van de wortel nqm en de functie van de nqm-teksten in het kader van de oudtestamentische Godsopenbaring, Boekencentrum, Zoetermeer.

Pettus, D.D., 1992, 'A canon-critical study of selected traditions in the book of Joel', PhD thesis, Faculty Publications and Presentations, Liberty University, Lynchburg, VA.

Philips, G.Y., Janse van Rensburg, F. \& Van Rooy, H.F., 2012, 'Developing an integrated approach to interpret New Testament use of the Old Testament', In die Skriflig/In Luce Verbi 46(2), Art. \#50, 10 pages. http:// dx.doi.org/10.4102/ids. v46i2.50.

Redditt, P.L., 1992, 'The book of Joel and peripheral prophecy', Catholic Biblical Quarterly 48, 225-240.

Russell, B.D., 2017, 'The Song of the Sea and the subversion of Canaanite myth A missional reading', in B.T. Arnold \& L.G. Stone (eds.), Distinctions with difference. Essays on myth, history and scripture in honour of John N. Oswalt, pp. 151-158, First Fruits Press, Wilmore, KY.

Schart, A., 2007, 'The first section of the Book of the Twelve Prophets: Hosea - Joel Amos', Interpretation 61(2), 138-152. https://doi.org/10.1177/002096430706100203

Scholtz, J., 2016, 'Vooronderstellings wat die eskatologie beïnvloed', In die Skriflig/In Luce Verbi 50(1), a2170. https://doi.org/10.4102/ids.v50i1.2170

Snyman, S.D., 2015, Malachi, Peeters, Leuven (Historical Commentary on the Old Testament).

Strine, C.A., 2016, 'Reconceiving prophecy: Activation, not prognostication', in C.M. Hays (ed.), When the Son of Man didn't come. A constructive proposal the delay of the Parousia, pp. 39-58, Fortress Press, Minnepolis, MN.

Sweeney, M.A., 2000, 'Sequence and interpretation of the Twelve', in J.D. Nogalski \& M.A. Sweeney (eds.), Reading and hearing the Book of the Twelve, pp. 49-64, Society of Biblical Literature, Atlanta, GA.

Sweeney, M.A., 2003, 'The priesthood and the proto-apocalyptic reading of the prophetic and Pentateuchal texts', in L.L. Grabbe \& R.D. Haak (eds.), Knowing the end from the beginning:The prophetic, the apocalyptic and their relationship, pp. 167-178, Clark International, London.
Talstra, E., 2014, 'Text, tradition, theology: The example of the book of Joel', in E. van der Borght \& P. van der Geest (eds.), Strangers and pilgrims on earth: Essays in honour of Abraham van de Beek, pp. 309-327, Brill, Leiden.

Thiselton, A.C., 2016, Discovering Romans: Content, interpretation, reception, SPCK, London.

Tiemeyer, L.-S., 2005, 'Prophecy as way of cancelling prophecy - The strategic uses of foreknowledge', Zeitschrift für alttestamentliche Wissenschaft 117(3), 329-350. https://doi.org/10.1515/zatw.2005.117.3.329

Toffelmire, C.M., 2014, 'Orienting the event: Register and the Day of YHWH in the prophetic book of Joel', PhD thesis, McMaster Divinity College, Hamilton, Ontario.

Towner, P.H., 1995, 'Paradigm lost: Mission to the Kosmos in John and in David Bosch's biblical models in mission', Evangelical Quarterly 67(2), 99-119.

Troxel, R.L., 2013, 'The problem of time in Joel', Journal for Biblical Literature 132(1), 77-95. https://doi.org/10.2307/23488238

Troxel, R.L., 2015, 'The fate of Joel in the redaction of the Twelve', Currents in Biblical Research 13(2), 152-174. https://doi.org/10.1177/1476993X13519888

VandenHooft, D., 2003, 'Babylonian strategies of imperial control in the West: Royal practice and rhetoric', in O. Lipschitz, G.N. Knoppers \& R. Albertz (eds.), Judah and the Judaeans in the fourth century BCE, pp. 235-262, Eisenbrauns, Winona Lake, IN.

Van der Kooi, C. \& Van den Brink, G., 2017, Christian dogmatics. An introduction, Wm. B. Eerdmans, Grand Rapids, MI.

Van der Woude, A.S., 1982, Haggai, Maleachi, Callenbach, Nijkerk (Prediking van het Oude Testament).

Van Rooy, H.F., 2017, 'Die missio Dei en die bestudering van die Ou Testament', In die Skriflig/In Luce Verbi 51(2), a2185. https://doi.org/10.4102/ids.v51i2.2185

Van Wyk, J.H., 2002, 'Die mens wik, maar God beskik? In gesprek met Adrio König oor sy eskatologiese, verbondsmatige voorsienigheidsleer', In die Skriflig/In Luce Verbi 36(4), 529-553. https://doi.org/10.4102/ids.v36i4.524

Viberg, A., 1994, 'Wakening a sleeping metaphor: A new interpretation of Malachi 1:11', Tyndale Bulletin 45(2), 297-319.

Weyde, K.W., 2000, Prophecy and teaching: Prophetic authority, form problems, and the use of traditions in the book of Malachi, De Gruyter, Berlin.

Wielenga, B., 1994, 'Zendingshermeneutiek: Een inleiding', in J. Bouma, J. Dekker, A.M. van Leeuwen et al. (reds.), Begeleidend schrijven. 25 Jaar Theologische Studiebegeleiding, pp. 224-235, Buijten \& Schipperheijn, Amsterdam.

Wielenga, B., 1998, Verbond en zending. Een verbondsmatige benadering van zending, Mondiss, Kampen.

Wielenga, B., 2002, 'Mission and the apocalyptic: A perspective from Matthew', International Review of Mission 91(360), 111-119. https://doi.org/10.1111/ j.1758-6631.2002.tb00333.x

Wielenga, B., 2009, 'Zending: Waarom? Het antwoord van Mattheus (28:16-20)', in P. Kleingeld (red.), Werkmap Missionair Steunpunt Nederlands Gereformeerde Kerken, pp. 15-19, Missionair Steunpunt NGK, Maassluis.

Wielenga, B., 2010, 'Bible reading in Africa - the shaping of a reformed perspective', In die Skriflig/In Luce Verbi 44(3\&4), 699-722. https://doi.org/10.4102/ids. $\mathrm{v} 44 \mathrm{i} 3 / 4.168$

Wielenga, B., 2013, 'Renewal and reconstruction: Holy Writ in Ezra-Nehemiah A missional reading', In die Skriflig/In Luce Verbi 47(1), a72. https://doi.org/ A missional reading,

Wielenga, B., 2015. 'Eschatological hope in Haggai: A homiletic reading', In die Skriflig/ In Luce Verbi 49(1), a1820. https://doi.org/10.4102/ids.v49i1.1820

Wielenga, B., 2016, 'Eschatology in Malachi: The emergence of a doctrine', In die Skriflig/In Luce Verbi 50(1), a2091. https://doi.org/10.4102/ids.v50i1.2091

Wright, C.H.J., 2016, 'Reading the Old Testament missionally', in M.W. Goheen (ed.), Reading the Bible missionally, pp. 107-123, Eerdmans, Grand Rapids, MI. 